\title{
Peanut Sheller using Screw Conveyor
}

\author{
Pratima G. Mungase ${ }^{\# *}$, A.D.Lokhande ${ }^{\#}$, Savita T. Mashalkar" ${ }^{\#}$ d Sangita A Soman ${ }^{\#}$ \\ \#MIT College of Engineering, Savitribai Phule Pune University, India
}

Accepted 02 March 2016, Available online 15 March 2016, Special Issue-4 (March 2016)

\begin{abstract}
Efforts are made to conserve our energy resources taking into account the rateat which it is depletingdue to the rising demands. Our proposed project makes an attempt to use manpower in crushing the shell of a peanut. The Sheller available in our vicinity uses electric energy; therefore using manpower ensures preservation of our resources to some extent. Lack of groundnut processing machines, especially groundnut Sheller, is a major problem of groundnut production, especially in our country India. The sprockets of a bicycle are rotated by pedaling action and this rotary motion is used to rotate the shaft of a screw conveyor. The peanut get crushed in between the flights around the shaft and the casing of the conveyor. Peanuts are delivered into the conveyor with the help of a hopper.
\end{abstract}

Keywords: Peanut Sheller, Screw Conveyor, Manpower, Bicycle.

\section{Introduction}

Agriculture plays a vital role in the Indian economy. Over 70 per cent of the rural households depend on agriculture. Agriculture is an important sector of Indian economy as it contributes about 17 per cent to the total GDP and provides employment to over 60 per cent of the population. Agriculture is the only means of living for almost two -thirds of the employed class in India. Hence it is very important to invent machines which can prove themselves very useful in farmers' point of view.

Groundnut is grown on small scale farmers in developing countries like India. Lack of groundnut processing machines, especially groundnut sheller, is a major problem of groundnut production, especially in our country India. In this project, designing and development of a machine to crush or shell groundnut so the farmers can gain high profit by selling groundnut direct in market.

The aim is to design a peanut sheller machine which uses manpower in place of conventional energy resources. The aim is to make it user friendly and cost efficient. It should be a onetime investment for the farmers. The machine should have a least maintenance and operational cost.

\section{Working}

Bicycle is a common man's vehicle and a screw conveyor is commonly used in agricultural products handling industries. We have collaborated them to

*Corresponding author: Pratima G. Mungase make a peanut Sheller. In the proposed Sheller, the sprockets of bicycle are rotated by pedaling action and this rotary motion is used to rotate the shaft of screw conveyor. The peanuts get crushed in clearance between the flights around the shaft and the casing of the conveyor. Peanuts are delivered into the conveyor with the help of hopper.

Screw conveyor is used in most of the industries for conveying various materials or products. In our proposed project we are using a screw conveyor for the purpose of both conveying and crushing peanut shells. The peanuts will be fed into the conveyor through hopper. The shaft of the conveyor is rotated by the pedaling action induced by a human sitting on bicycle. The shaft is connected to the rear sprocket of the bicycle. Via chain drive the rotation is transmitted to the rear sprocket and then to the shaft. Through our project we are trying to design the screw conveyor in such a way that the clearance between theflights of the conveyor and the casing around it crushes the shells of the peanut instead of just passing it forward.

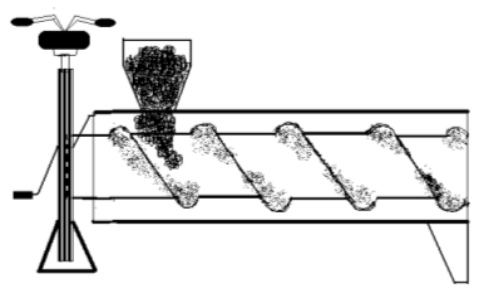

Fig.1Proposed Design of Peanut Sheller

We are making an effort to increase the comfort by making it a pedal operated. As the force produced by 
our thigh bones are much higher than limb force it increases the output rate. Also hand operated machine lacks an outlet. We are having an outlet to the mixture of peanut and crushed shells.

\section{Design}

\subsection{Data}

Bulk Density of Peanut $=480-720 \mathrm{~kg} / \mathrm{m}^{3}$

Peanut Characteristic $=$ Abrasive

Working Temperature $=25-30{ }^{\circ} \mathrm{C}$

Profile of Screw Conveyor $=$ Horizontal

Required Capacity $=150 \mathrm{~kg} / \mathrm{hr}$

Trough Loading $=\mathrm{K}=60 \%$

Length of Pipe $=1.5 \mathrm{~m}$

Length of Screw Conveyor $=1.2 \mathrm{~m}$

Screw Diameter $=D_{s}=150 \mathrm{~mm}$

Pipe Diameter $=D_{p}=50 \mathrm{~mm}$

Pitch $\left(\right.$ Short Pitch Screw) $=\mathrm{P}=\mathrm{D}_{\mathrm{s}} / 2=75 \mathrm{~mm}$

1. Capacity/hour/rpm:

(According to CEMA code)

Formula:

Capacity $/ \mathrm{hr} / \mathrm{rpm}=\left(0.785^{*}\left(\mathrm{Ds}^{2}-\mathrm{Dp}^{2}\right)^{*} \mathrm{P} * \mathrm{~K}^{*} 60\right)$

Where, $\mathrm{K}=$ Percentage trough loading

Capacity/hour/rpm=

$0.785^{*}\left(0.15^{2}-0.05^{2}\right) * .075^{*} 0.6 * 60$

$=0.04239 \mathrm{~m}^{3} /$ hour

2. (Capacity/hour/rpm) $*$ bulk density $=0.04239 * 480$ Capacity $(\mathrm{kg} / \mathrm{hour} / \mathrm{rpm})=20.3472 \mathrm{~kg} /$ hour $/ \mathrm{rpm}$

3. Required capacity $=150 \mathrm{~kg} /$ hour

Speed $(\mathrm{rpm})=$

(Required capacity) / (Capacity in kg/hour/rpm)

Speed $=150 / 20.3472$

Speed $=7.37 \mathrm{rpm} \sim 8 \mathrm{rpm}$

\subsection{Power Calculations}

Power consumed to overcome friction,

$$
\mathrm{HP}_{\mathrm{f}}=\mathrm{L}^{*} \mathrm{~N}^{*} \mathrm{~F}_{\mathrm{d}} * \mathrm{~F}_{\mathrm{b}} / 10^{6}
$$

Where,

$\mathrm{L}=$ Length of the conveyor $=1.5 \mathrm{~m}$

$\mathrm{N}=$ Speed in $\mathrm{rpm}$

$F_{d}=$ Conveyor diameter factor $=31$

$\mathrm{F}_{\mathrm{b}}=$ Hanger bearing factor $=1$

$\mathrm{HP}_{\mathrm{f}}=0.0012$

Power to transport material at specified rate,

$\mathrm{HP}_{\mathrm{m}}=\left(\mathrm{C}^{*} \mathrm{~L}^{*} \mathrm{~W}^{*} \mathrm{Ff}^{*} \mathrm{Fm}^{*} \mathrm{Fp}\right) / 10^{6}$

Where,

$\mathrm{C}=$ Capacity in $\mathrm{ft}^{3} /$ hour $=1.497$

$\mathrm{L}=$ Total length $=1.2 \mathrm{~m}=3.94 \mathrm{ft}$

$\mathrm{W}=$ Apparent density $\left(\mathrm{lbs} / \mathrm{ft}^{3}\right)=29.95$

$\mathrm{F}_{\mathrm{f}}=$ Flight factor $=1$

$\mathrm{Fm}=$ Material factor $=2$

$\mathrm{Fp}=$ Paddle factor $=1$

$\mathrm{HP}_{\mathrm{m}}=0.00035 \mathrm{HP}$
Table 1Flight Modification HP Factor $F_{f}$

\begin{tabular}{|c|c|c|c|c|}
\hline \multirow{2}{*}{$\begin{array}{c}\text { Type of } \\
\text { Flight }\end{array}$} & \multicolumn{4}{|c|}{ Conveyor Loading } \\
\cline { 2 - 5 } & $15 \%$ & $30 \%$ & $45 \%$ & $95 \%$ \\
\hline Standard & 1 & 1 & 1 & 1 \\
\hline Cut & 1.1 & 1.15 & 1.2 & 1.3 \\
\hline $\begin{array}{c}\text { Cut \& } \\
\text { Folded }\end{array}$ & NR & 1.5 & 1.7 & 2.2 \\
\hline Ribbon & 1.05 & 1.14 & 1.2 & NR \\
\hline
\end{tabular}

Std. Paddles per Pitch Set at $45^{\circ}$ Reverse Pitch

Table 2Paddle HP Factor, Fp

\begin{tabular}{|c|c|c|c|c|}
\hline None & 1 & 2 & 3 & 4 \\
\hline 1 & 1.29 & 1.58 & 1.87 & 2.16 \\
\hline
\end{tabular}

\subsection{Calculation for Efficiency}

Assuming the power developed by a normal average human being to be 300 watts. Therefore, initial power developed,

$\mathrm{P}_{1}=300$ watts $=0.4 \mathrm{HP}$.

Assuming chain drive efficiency,

$$
\mathrm{E}_{1}=80 \%
$$

$\mathrm{E}_{1}=$ Output Power / Input Power

Output power, $\mathrm{P}_{2}=0.32 \mathrm{HP}=$ Power available at the conveyor

Power available for crushing,

$$
\begin{aligned}
& \mathrm{P}_{3}=0.32-\left(\mathrm{HP}_{\mathrm{f}}+\mathrm{HP}_{\mathrm{m}}\right) \\
& \mathrm{P}_{3}=0.318 \mathrm{HP}
\end{aligned}
$$

Efficiency, $\mathrm{E}_{2}=\mathrm{P}_{3} / \mathrm{P}_{2}$

$$
\mathrm{E}_{2}=99.5 \%
$$

Overall Efficiency, $\mathrm{E}_{0}=\mathrm{E}_{1} * \mathrm{E}_{2}$ $\mathrm{E}_{0}=79.61 \%$

\subsection{Calculation for Deflection}

Deflection $=\left(5^{*} \mathrm{~W}^{*} \mathrm{~L}^{3}\right) /\left(384^{*} \mathrm{E}^{*} \mathrm{I}\right)$,

Where $\mathrm{E}=210 * 10^{9} \mathrm{~N} / \mathrm{m}^{2}$

$$
\begin{aligned}
\mathrm{L} & =1.5 \mathrm{~m} \\
\mathrm{I} & =6.13^{*} 10^{-7} \mathrm{~m}^{4} \\
\mathrm{~W} & =21.60 \mathrm{~kg}=211.9 \mathrm{~N} \\
\mathrm{~d} & =0.0723 \mathrm{~mm}<3 \mathrm{~mm}, \text { Hence Safe. }
\end{aligned}
$$

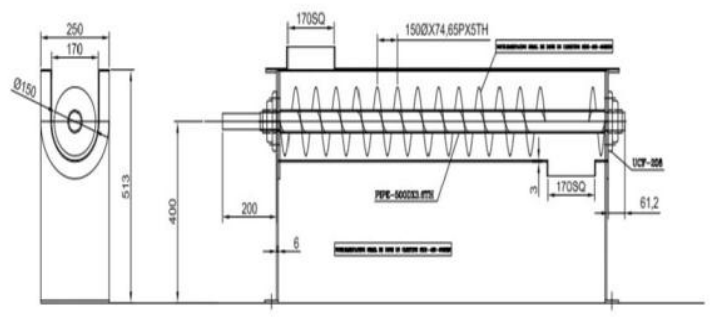

Fig.2Drawing of Screw Conveyor 
No. of flights $=14$

Calculations for Clearance

\section{A) For Shelled Peanuts}

Table3 Dimensions of Shelled Peanuts

\begin{tabular}{|c|c|}
\hline Length(mm) & Thickness(mm) \\
\hline 27.5 & 10.8 \\
\hline 19.52 & 10.1 \\
\hline 21.48 & 12 \\
\hline 35.1 & 12.26 \\
\hline
\end{tabular}

Average Length $=25.9 \mathrm{~mm}$ Average Thickness $=11.29 \mathrm{~mm}$

\section{B) For Unshelled Peanuts}

Table4 Dimensions of Unshelled Peanuts

\begin{tabular}{|c|c|}
\hline $\begin{array}{c}\text { Length(m } \\
\mathrm{m})\end{array}$ & $\begin{array}{c}\text { Thickness(m } \\
\mathrm{m})\end{array}$ \\
\hline 15.14 & 0.63 \\
\hline 16.1 & 0.62 \\
\hline 13.2 & 0.5 \\
\hline 12.1 & 0.9 \\
\hline
\end{tabular}

Average Length $=14.35 \mathrm{~mm}$

Average Thickness $=0.66 \mathrm{~mm}$

Clearance $=10 \mathrm{~mm}$

The selected clearance between the trough and the flights of screw conveyor is $10 \mathrm{~mm}$ for better crushing of peanut shells but not of the peanuts.

\section{Conclusions}

The manually operated peanut Sheller by using screw conveyor is easy to use hence does not require any skilled person.
It is operated by pedaling action hence ensures comfort as compared to hand operated machines. It is also provided with a separate outlet. he scope of improvement in this model is the inclusion of separation mechanism using either a fan or a sieve. Fan can be operated by utilizing solar power. Speed can be increased by using a gear pair.

\section{References}

A.N.Gitaul, P. Mboya, B. N. K. Njoroge, M.Mburu,(2013) 'Optimizing the Performance of a Manually Operated Groundnut (Arachis hypogaea) Decorticator', Open Journal of Optimization, Pg. No. 26-32.

Ashish S. Raghtate, Dr. C.C. Handa, (2014)'Design Consideration of Groundnut Sheller Machine', IJIRSTInternational Journal for Innovative Research in Science and Technology, Volume 1, Issue 4, Pg. No. 41-46.

CEMA Catalogue (Conveyor Equipment Manufacturing Association)

Hemad Zreiforoush, Mohammad Hasan Komarizadeh, Mohammad Reza Alizadeh',(2010), 'Performance Evaluation of a $15.5 \mathrm{~cm}$ Screw Conveyor during Handling Process of Rough Rice ( Oriza Sativa L.) Grains, Nature and Science, Pg. No. 66-74.

Ikechukwu Celestine Ugwuoke, Olawale James Okegbile, Ibukun Blessing Ikechukwu, (2014), 'Design and Fabrication of Groundnut Shelling and Separating Machine', International Journal of Engineering Science Inventions, Volume 3 Issue 4, PP. 60-66.

Screw Conveyor Catalogue and Engineering Manual by Continental Conveyor and Machines Work Ltd. Canada.

Screw Conveyor Components and Design Version 2.20 by Conveyor Engineering and Manufacturing. 